\title{
Targeting the intestinal TMPRSS2 protease to prevent SARS-CoV-2 entry into enterocytes-prospects and challenges
}

\author{
Ismail Sami Mahmoud ${ }^{1}$ (D) . Yazun Bashir Jarrar ${ }^{2}$ (D)
}

Received: 2 March 2021 / Accepted: 29 April 2021 / Published online: 22 May 2021

(c) The Author(s), under exclusive licence to Springer Nature B.V. 2021

\begin{abstract}
The transmembrane protease serine 2 (TMPRSS2) is a membrane anchored protease that primarily expressed by epithelial cells of respiratory and gastrointestinal systems and has been linked to multiple pathological processes in humans including tumor growth, metastasis and viral infections. Recent studies have shown that TMPRSS2 expressed on cell surface of host cells could play a crucial role in activation of severe acute respiratory syndrome coronavirus 2 (SARS-CoV-2) spike protein which facilitates the rapid early entry of the virus into host cells. In addition, direct suppression of TMPRSS2 using small drug inhibitors has been demonstrated to be effective in decreasing SARS-CoV-2 infection in vitro, which presents TMPRSS2 protease as a potential therapeutic strategy for SARS-CoV-2 infection. Recently, SARS-CoV-2 has been shown to be capable of infecting gastrointestinal enterocytes and to provoke gastrointestinal disorders in patients with COVID-19 disease, which is considered as a new transmission route and target organ of SARS-CoV-2. In this review, we highlight the biochemical properties of TMPRSS2 protease and discuss the potential targeting of TMPRSS2 by inhibitors to prevent the SARS-CoV-2 spreading through gastro-intestinal tract system as well as the hurdles that need to be overcome.
\end{abstract}

Keywords SARS-CoV-2 $\cdot$ TMPRSS $2 \cdot$ Serine protease $\cdot$ Enterocytes $\cdot$ Drug inhibitor

\section{Background}

Severe acute respiratory syndrome coronavirus 2 (SARS$\mathrm{CoV}-2)$ is the cause of current pandemic coronavirus disease 2019 (COVID-19). The virus is primarily thought to infect the lungs to provoke severe acute respiratory syndrome. However, recent reports have suggested that the virus could infect other organs such as gastrointestinal tract, kidneys and liver [1-3].

The SARS-CoV-2 entry mechanism in host cells is mediated by two main pathways which involved two key proteins located on the surface of epithelia of the lung and small intestine. The first pathway is occurred by engagement of

Ismail Sami Mahmoud

ismails@hu.edu.jo

Yazun Bashir Jarrar

yazun.jarrar@zuj.edu.jo

1 Department of Medical Laboratory Sciences, Faculty of Allied Health Sciences, The Hashemite University, Zarqa 13133, Jordan

2 Department of Pharmacy, Alzaytoonah University of Jordan, Amman, Jordan
SARS-CoV-2 spike (S) glycoprotein with angiotensin converting enzyme II (ACE2), whereas the second is induced by the transmembrane protease serine 2 (TMPRSS2) protease that cleaves the (S) glycoprotein of SARS-CoV-2 to generate unlocked fusion- catalyzing form of the virus and facilitates its entry to host cells via direct fusion of the viral and plasma membrane leading to release of the viral ssRNA into the cytoplasm [4].

Recent reports have shown that SARS-CoV-2 could potentially infect enterocytes of gastrointestinal tract in humans [5]. Indeed, several clinical studies have demonstrated gastrointestinal manifestations including diarrhea, vomiting and abdominal pain in patients infected with SARS-CoV-2 [6-8]. In this review, we shed some light on the biochemical properties of TMPRSS2 protease and the potential use of therapeutics to specifically target TMPRSS2 and block its function to abrogate the entry of SARS-CoV-2 into enterocytes of gastrointestinal system. 


\section{Biochemistry of TMPRSS2 protease}

The transmembrane protease serine 2 (TMPRSS2) is a member of Hepsin/TMPRSS subfamily of type II transmembrane serine proteases (TTSP) which also includes TMPRSS1 (Hepsin), TMPRSS3, TMPRSS4, TMPRSS5 (Spinesin) and TMPRSS13 [Mosaic serine protease large form (MSPL)] [9]. TMPRSS2 is thought to play a key role in prostate epithelial cell biology, and its prominent association with prostate carcinogenesis has led to the proposal that it may be a therapeutic or diagnostic marker for prostate cancer [10].

The gene encoding TMPRSS 2 resides at chromosome 21 , and has 15 exons and an open reading frame of 492 amino acids [11]. TMPRSS2 gene expression has been shown to be positively regulated by androgen hormone in prostate cancer cells, where the expression of TMPRSS2 gene was significantly reduced during androgen deprivation [10]. Later studies conducted to understand mechanisms behind the androgen regulation of the TMPRSS2 gene expression have identified key androgen receptor binding sites (ARBS) at $\sim 13 \mathrm{~Kb}$ upstream of the TMPRSS2 gene transcription start site [12].

TMPRSS2 protein is $\sim 70 \mathrm{kDa}$ and comprises several domains (Fig. 1): an N-terminal intracellular cytoplasmic domain (amino acid residues 1-84), a transmembrane region (residues 85-105), and a C-terminal extracellular region (residues of 106-492) that contains an LDL receptor class A- like domain (it represents a binding site for calcium), a scavenger receptor cysteine-rich (SRCR) domain (involved in binding to extracellular molecules), and a serine protease domain that cleaves at arginine (Arg) or lysine (Lys) (residues 256-489) [9, 13]. The $70 \mathrm{kDa}$ TMPRSS2 is made as a precursor protein (zymogen) which has been shown to undergo autoproteolytic activation in prostate cancer cells [14]. The protease domain of TMPRSS 2 belongs to the S1 family of serine proteases that cleave at Arg or Lys residues, and it shares a high degree of amino acid sequence identity with other members of TTSP, in particular, the histidine, aspartate, and serine residues which are necessary for catalytic activity [15]. Furthermore, the protein sequence of TMPRSS2 reveals that it has three Arg residues (Arg240, Arg252, and Arg255) near the N-terminus of the protease domain of TMPRSS2 [14]. Previous experiments performed using site-directed mutagenesis showed that an autoproteolytic cleavage of TMPRSS 2 could occur primarily at Arg-255 and resulted in the release of the protease domain $(32 \mathrm{kDa})$ to extracellular space [14]. However, the autocleavage process of TMPRSS2 has not been reported in other tissues than prostate cancer cells, and whether the mechanism is tissue specific or it is generally required for TMPRSS 2 activation in various tissues still to be defined.

\section{TMPRSS2 mediates entry of SARS-CoV-2 into human cells}

TMPRSS2 protease activity is currently considered as a key mechanism for SARS corona virus entry and pathogenesis in host cells $[16,17]$. Indeed, it has been demonstrated that TMPRSS2 cleaves the coronavirus (S) glycoprotein to generate unlocked, fusion-catalyzing forms of the (S) glycoprotein at the cell surface of host cells which facilitate rapid entry of the virus into cells [18]. Also, Yoshikawa and his
Fig. 1 Structural domains of TMPRSS2 protein. A linear map of structural domains of TMPRSS2 protein. The C-terminus $(\mathrm{COOH}$ end) contains the key domains; serine protease domain, required for cleavage of the virus (S) protein, and the scavenger receptor cysteine rich domain and LDL class $\mathrm{A}$ like receptor which are required for binding to extracellular molecules and calcium binding, subsequently. It also contains a transmembrane domain (TM) for membrane anchoring and an intracellular N-terminus ( $\mathrm{NH} 2$ end) cytoplasmic tail for appropriate intracellular trafficking. The figure was created using BioRender.com

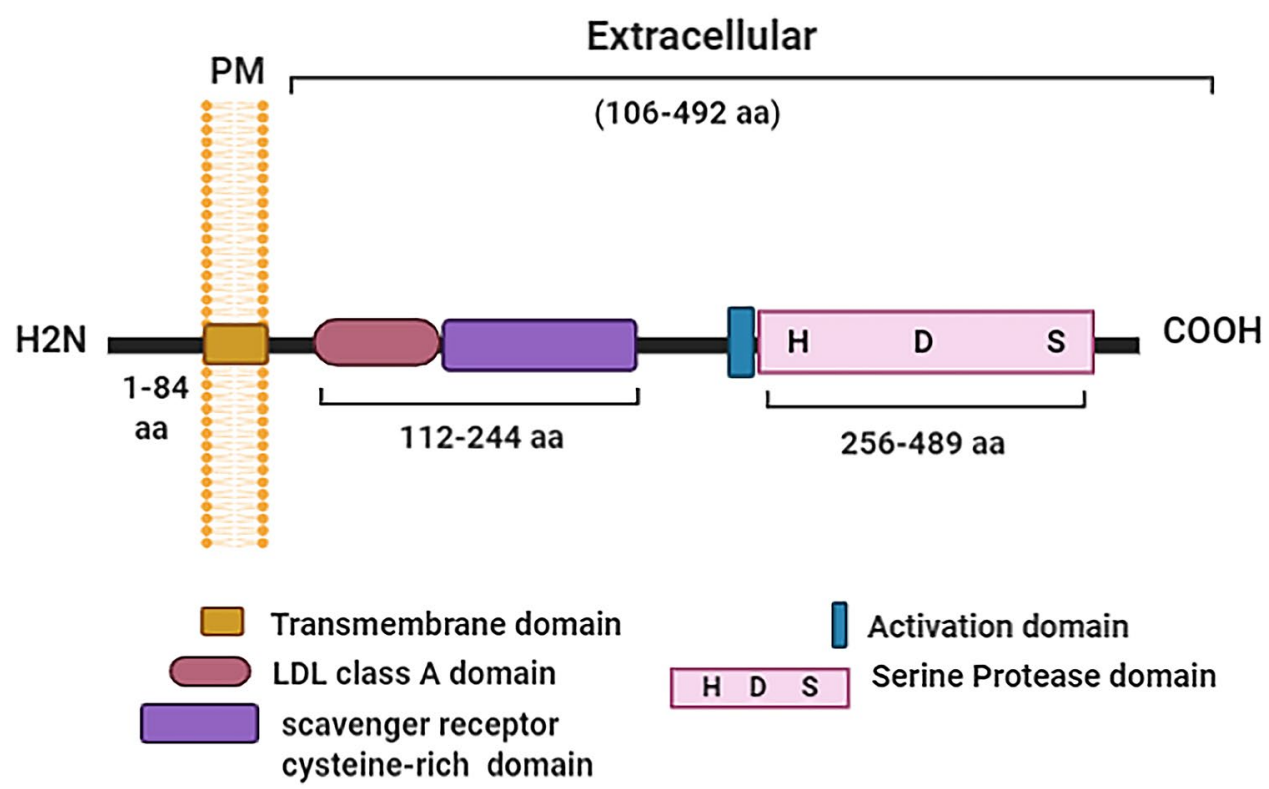


colleagues have used TMPRSS2-knockout (KO) mice which experimentally infected with SARS-CoV and MERS-CoV, and their results suggested that the lack of TMPRSS 2 in the respiratory airways reduced the severity of lung immunopathology after infection by SARS-CoV and MERS-CoV [19]. Just recently, it has been shown that the TMPRSS2expressing kidney epithelial cell line (VeroE6) was highly susceptible to SARS-CoV-2 infection [20], indicating that the TMPRSS2 protease activates the viral (S) glycoprotein for direct membrane fusion mechanism and is crucial for virus entry into host cells.

On the other hand, it is widely accepted that the human angiotensin converting enzyme II (ACE2) is involved in SARS-CoV-2 binding and entry into human target cells [21]. Briefly, the receptor-binding domain (RBD) of the SARS (S) glycoprotein binds to the tip of subdomain I of ACE2 [22], which then induced endocytosis of the virus that ends up in endosomal compartments, where an increase in $\mathrm{H}+$ influx into the endosome activates cathepsin $\mathrm{L}$ enzymes which activate viral (S) glycoprotein and facilitate viral membrane fusion and release of ssRNA out of the endosome [4].
It has been suggested that TMPRSS2 may also play a role in ACE2-mediated entry of SARS-CoV. Indeed, Heurich and his colleagues have shown that the co-expression of TMPRSS2 and ACE2 in 293T cells resulted in cleavage of ACE2 with a generated C-terminal ACE2 fragment of $\sim 13 \mathrm{kDa}$ which can be detectable in cell lysates, and the cleavage of ACE2 by TMPRSS2 resulted in augmented SARS-CoV entry into host cells [18]. Interestingly, SARS$\mathrm{CoV}$ (S) glycoprotein binding to ACE2 could also induce cleavage of ACE2 by TMPRSS2, and it has been suggested that the SARS-CoV (S)-mediated shedding of ACE2 may increase the cellular uptake mechanism of virus particles by endocytosis $[18,23]$.

In conclusion, upon SARS-CoV-2 binding to the cell surface of a host cell, TMPRSS2 could induce viral entry into the cell by two proposed mechanisms; firstly by direct SARS-(S) glycoprotein cleavage, which activates the (S) glycoprotein for membrane fusion. Secondly by cleavage of ACE2, which then augments viral uptake through the receptor mediated endocytosis/cathepsin L-dependent pathway (Fig. 2).

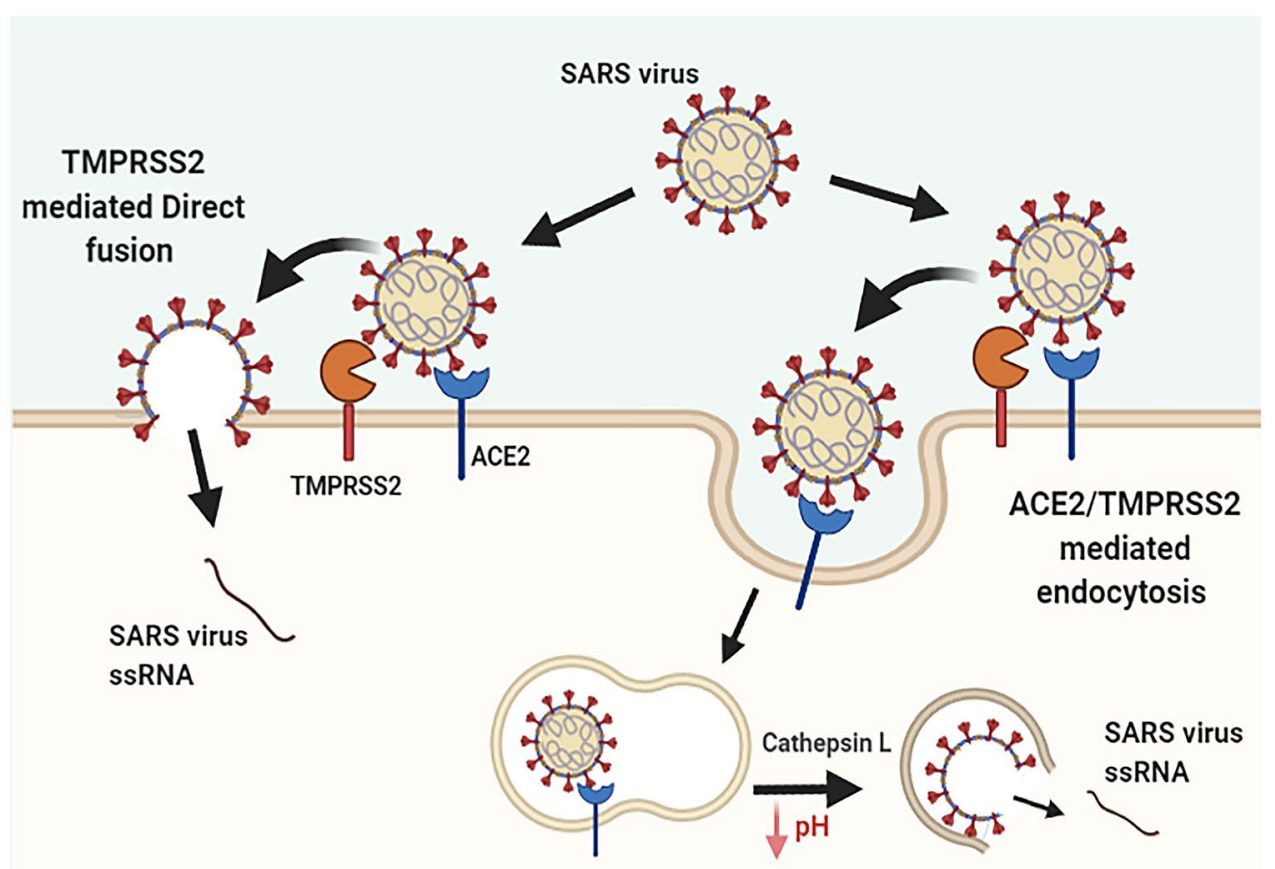

Fig. 2 TMPRSS2 mediated entry of SARS-CoV-2 into host cells. Upon SARS-CoV-2 binding to the cell surface, TMPRSS2 could potentially activate the virus entry into host cells by at least two main pathways. (Left) TMPRSS2 on the host cell surface mediates the proteolytic cleavage of the viral $(\mathrm{S})$ protein which induces direct fusion of the viral and plasma membrane leading to release of the viral ssRNA into the cytoplasm. (Right) Alternatively, TMPRSS2 may cooperate with host cell receptor ACE2 in activation of SARSCoV-2 (S) protein which then stimulates receptor mediated endocytosis, subsequently SARS-CoV-2 ends in endosomal compartments, where a decrease in endosomal $\mathrm{pH}$ stimulates cathepsin $\mathrm{L}$ enzymes which further cleave and activate viral (S) glycoprotein and facilitate the release of the viral ssRNA into the cytosol. The figure was created using BioRender.com 


\section{TMPRSS2 and SARS-CoV-2 infection of gastrointestinal tract system}

Having that both ACE2 and TMPRSS2 are highly expressed in the gastro-intestinal tract (GIT), in particular by intestinal epithelial cells, which makes this region as a target for many enteric viruses including SARS-CoV-2. Indeed, SARS-CoV-2 could potentially infect the GIT system in humans [5]. In fact, it has been reported that some patients infected with SARS-CoV-2 have demonstrated gastrointestinal manifestations such as diarrhea, vomiting and abdominal pain $[6,7,24]$. Additionally, in the first case of COVID-19 infection confirmed in the United States, Holshue et al., 2020 have shown the detection of SARS-CoV-2 RNA in a stool specimen collected from the patient on day 7 of the patient's illness [25]. In a recent study conducted on 73 hospitalized patients infected with SARS-CoV-2 in China, it has been reported that about half of the patients tested positive for SARS-CoV-2 RNA in stool samples [2]. Also, in the same study, using immunofluorescent microscopy imaging technique, Xiao and his colleagues have shown that ACE2 protein was abundantly expressed in the glandular cells of gastric, duodenal, and rectal epithelia of a hospitalized patient infected with SARS-CoV-2 [2], which further supports the entry of SARS-CoV-2 into host GIT cells.

In another study, Lee et al., have utilized the human intestinal cell line (C2BBe1), characterized by high levels of TMPRSS2 and ACE2, to study the role of ACE2 and TMPRSS2 in SARS-CoV-2 infection of GI tract. The authors found that the cells demonstrated persistent infection with SARS-CoV-2 and robust viral propagation [26]. It's noteworthy to mention that the $\mathrm{C} 2 \mathrm{BBe} 1$ cells are brush border expressing cells with microvilli resembling the brush border of human intestinal epithelia [26].

On the other hand, Zang and colleagues have shown that TMPRSS2 and TMPRSS4 serine proteases could facilitate the SARS-CoV-2 infection of human duodenum enteroids, isolated from human subjects and cultured in vitro, by inducing cleavage of the (S) glycoprotein and enhancing membrane fusion [27]. Also, they showed that human intestinal epithelial cells were predominantly infected by SARSCoV-2 from the apical surface compared to the basolateral side [27]. Moreover, the co-expression of TMPRSS2 with ACE2 resulted in enhanced infectivity of SARS-CoV-2 in HEK293 cells [27]. Strikingly, recent studies have found high degree of co-expression correlation between ACE2 and TMPRSS2 in different human tissues, including salivary and thyroid glands, kidney, gallbladder, colon duodenum, small intestine [28] and lung tissues [29].

To sum up, there are several evidences coming from different research labs and clinical studies which claim the potential capability of SARS-CoV-2 to infect the GIT by a specific mechanism, and it seems that ACE2 and TMPRSS2 are main players in this mechanism. But, how could SARS-CoV-2 provoke GIT disorders is still to be elucidated, it could be the binding of the virus on the apical surface of intestinal enterocytes mediated by ACE2-TMPRSS2 system may cause a deregulation of the sodium dependent transmembrane transporters such as $\mathrm{Na}+/ \mathrm{H}+$ exchangers (NHEs) and sodium-glucose transport protein (SGLT1) located along the intestine that results in GIT manifestations such as diarrhea and abdominal pain [30, 31]. However, further research is necessary to validate such hypothesis.

\section{Targeting of TMPRSS2 to prevent SARS-CoV-2 entry to GI tract enterocytes- potential drugs}

Inhibition of TMPRSS2 could prevent SARS-CoV-2 entry into human lung cells and hence the viral respiratory infection. Indeed, it has been found that knocking-out of mouse tmprss 2 gene protected against SARS-CoV infection [19]. Although multiple types of research investigated the influence of inhibiting TMPRSS2 on SARS-CoV-2 infection in the lung [32, 33], still there are no reported studies to show clearly the effect of targeting TMPRSS2 on the SARSCoV-2 mediated GIT infection. However, it has been suggested that targeting of TMPRSS 2 and TMPRSS 4 could be potentially used to reduce the GIT infection induced by SARS-CoV-2 virus [27].

Generally, most of drugs available against TMPRSS2 can be classified into two main categories: drugs that inhibit TMPRSS2 activity by either direct chemical interaction between the drug inhibitor and TMPRSS [34] or down regulate the mRNA expression of the TMPRSS2 gene [35]. Drugs that showed inhibitory activity against TMPRSS2 and are used currently as mucolytic, anti-inflammatory, and anticoagulant drugs. For example, bromhexine and its potent metabolite ambroxol are used clinically to suppress excess pulmonary mucosal secretions and hence suppress the productive cough [36]. Bromhexine and ambroxol reduce the secretion of inflammatory mediators, such as interleukins and tumor necrosis factor-alpha (TNF- $\alpha$ ), therefore bromhexine and ambroxol have an anti-inflammatory effect [37]. Additionally, ambroxol was found to suppress the proliferation of influenza virus in mouse lungs [38]. Interestingly, bromhexine has been demonstrated to inhibit TMPRSS2 using both in vitro and in vivo methods [39], indicating that the drug could be utilized as protective agents against SARS-CoV-2 infection. Just recently, it has been shown that bromhexine reduced clinically the SARS-CoV-2 infection in a clinical trial conducted in Iran 
[40]. Notably, the drug significantly reduced the intensive care unit (ICU) transfer, intubation, and the mortality rate in patients with COVID-19 [38]. However, it was observed elsewhere that both bromhexine and ambroxol can cause a GIT disturbance, such as nausea, vomiting, and diarrhea [41]. Unfortunately, these unwanted side effects of bromhexine and ambroxol may worse the clinical symptoms among SARS-CoV-2 infected patients, who may be already suffer from GIT problems [42].

Aprotinin, camostat, and nafamostat are anti-coagulant drugs that used clinically in the treatment of thrombotic diseases [43, 44]. In fact, camostat is used in Japan for treatment of pancreatitis [45]. These drugs inhibit plasmin, kallikrein, and thrombin and also have anti-inflammatory activity through reducing the levels of interleukin-6, interleukin- 8 and TNF- $\alpha[46,47]$.

Strikingly, in a recent study using in silico methods, it has been pointed out that aprotinin can inhibit the serine protease activity of TMPRSS2 [48]. Also, it has been reported that aprotinin inhibited the replication of SARSCoV-2 in non-small-cell lung cancer (Clu-3) and colon carcinoma (Caco2) cells and primary bronchial epithelial cells [49]. Additionally, aprotinin decreased the rate of mortality caused by influenza infection using in vivo mouse models [50]. In fact, aprotinin is used clinically, in Russia, for treatment of mild to moderate influenza [50]. Since TMPRSS2 plays a major role in the entry of both influenza and SARS$\mathrm{CoV}-2$ virus, it can be speculated that aprotinin can protect clinically against SARS-CoV-2 infection by inhibiting the activity of TMPRSS2.

On the other hand, camostat and nafamostat can inhibit TMPRSS2 through chemical interaction with Asp435, Ser441, and His296 residues which are essential for proper protease activity of TMPRSS2 protein [51]. Also, the compounds were shown to reduce the rate of SARS-CoV-2 entry into Calu-3 lung cells, simian kidney Vero E6 cells, and cervical cancer HeLa cells [17]. Furthermore, it was found that nafamostat inhibited MERS-CoV (S) protein-mediated viral entry to the lung cells [52], which shares similar serine protease activity with the SARS-CoV-2 virus. Notably, both camostat and nafamostat drugs have mild to moderate disturbance to the gastro-intestinal tract [53]. Making these drugs as promising candidates to prevent SARS-CoV-2 infection of GIT system. However, camostat is considered relatively safer than nafamostat, which may cause agranulocytosis, hyperkalemia, anaphylaxis, and cardiac arrest [54, 55].

Searching for natural and safer drugs, Roomi and Khan, used in silico methods for discovering potential natural compounds that can inhibit TMPRSS2 [48]. They found several natural compounds, such as salannin, deacetylsalannin, nimbolin, nobiletin, pinostrobin, sakuranetin, umuhengerin and eucalyptin, which bind with variable affinity to different amino acid residues in TMPRSS2 protein. However, further in vitro and in vivo experiments are needed to confirm these in silico findings.

On the other side, it can be proposed that drugs that downregulate TMRPSS2 expression may be useful in decreasing SARS-CoV-2 entry and infection, compared with drugs that up-regulate TMRPSS2 expression may exacerbate SARSCoV-2 infection. It is found that sexual hormones modulate the expression of TMPRSS2 gene [56]. Usually, the sexual hormones are prescribed clinically in the treatment of hormonal disturbance, hypogonadism, and as contraceptives [57]. Besides, athletes used to take androgenic drugs, such as oxandrolone for performance enhancement [58]. It was found that estradiol, genistein and phytoestrogen could down regulate TMPRSS2 mRNA expression [59]. These drugs act by modulating the nuclear estrogen receptor expression. Additionally, it has been shown that the androgen receptor antagonist enzalutamide down regulated significantly the mRNA expression of the TMPRSS2 gene [59]. On the other hand, testosterone, synthetic androgens, and estrogen receptor antagonist fulvestrant up-regulated significantly the mRNA expression of the TMPRSS2 gene [59]. Moreover, Chu et al., have demonstrated that androgen receptor (AR) negative prostate cancer ( $\mathrm{PCa}$ ) cells showed hypermethylation and low expression levels of TMPRSS2 gene, compared to AR-positive prostate cells which displayed hypomethylation and low expression levels of TMPRSS2 gene [35]. Interestingly, treatment of the AR-negative prostate cells with the 5-Aza-2'-deoxycytidine (an inhibitor of DNA methylation) reversed the low expression levels of TMPRSS2 [35]. The authors found that the activation of nuclear androgen receptor reduced epigenetically the methylation of TMPRSS2 gene which lead to an increase in TMPRSS 2 mRNA expression [35]. In another study, it was also observed through analyzing human post-mortem lung tissues that the level of TMPRSS2 mRNA expression is inversely correlated with estrogen treatment [59]. Indicating that estrogen treatment may reduce the expression of TMPRSS2 and consequently inhibit the entry of the virus into cells. Interestingly, emerging global data shows that men appear to be at higher risk of SARS-CoV-2 infection and mortality than women [60, 61]. Thus, we think that sex hormones including estrogen and androgen may play a role in COVID-19 disease by at least the regulation of TMPRSS2 expression and subsequent effect on virus entry mechanism into host cells.

\section{Conclusion}

The recent findings of potential GIT infection by SARS$\mathrm{CoV}-2$ has opened a new door for potential fecal-oral transmission route of the virus and for developing new strategies to prevent the transmission of the virus, as well as finding new therapeutics for COVID-19 disease. 
Table 1 Potential inhibitors of TMPRSS2 enzymes

\begin{tabular}{|c|c|c|c|}
\hline Drugs & Family & Mechanism of action & Refs \\
\hline \multicolumn{4}{|l|}{ Direct inhibitors of TMPRSS2 enzyme } \\
\hline Bromhexine and ambroxol & Mucolytics and expectorants & $\begin{array}{l}\text { Disrupts the structure of mucopolysac- } \\
\text { charide fibres in mucoid sputum }\end{array}$ & {$[62]$} \\
\hline Aprotinin & Antifibrinolytic & Pancreatic trypsin inhibitor & [63] \\
\hline Camostat & Anti-inflammatory of pancreas & Serine protease inhibitor & {$[64]$} \\
\hline Nafamostat & $\begin{array}{l}\text { Anti-coagulant and Anti-inflam- } \\
\text { matory of pancreas }\end{array}$ & Serine protease inhibitor & {$[65]$} \\
\hline $\begin{array}{l}\text { Salannin, deacetylsalannin, nimbolin, nobiletin, } \\
\text { pinostrobin, sakuranetin, umuhengerin and euca- } \\
\text { lyptin }\end{array}$ & Natural products & $\begin{array}{l}\text {-Insecticidals } \\
\text {-Anticancer } \\
\text {-Anti-inflammatory } \\
\text {-Antiallergic }\end{array}$ & [66-69] \\
\hline \multicolumn{4}{|l|}{ Down-regulators of TMPRSS2 RNA expression } \\
\hline Estradiol & Synthetic estrogen & Agonists of nuclear estrogen receptors & {$[70]$} \\
\hline Genistein and phytoestrogen & Natural estrogens & Agonists of nuclear estrogen receptors & {$[71]$} \\
\hline Enzalutamide & Androgen receptor antagonist & $\begin{array}{l}\text { Preventing androgen to bind to the } \\
\text { nuclear androgen receptor }\end{array}$ & {$[72]$} \\
\hline
\end{tabular}

The identification of compounds that specifically targets TMPRSS2 and selectively partition into the gastrointestinal tract would be of high interest given the recent evidences demonstrating the key mechanism of the virus entry mediated by TMPRSS 2 localized in this region that can impact SARS-CoV-2 disease. There are many of promising potential drugs available that have been described in the literature with capability to inhibit TMPRSS2 (Table 1) either by direct inhibition of the enzyme such as bromhexine, ambroxol, camostat and nafamostate, or by deregulation of TMPRSS 2 gene expression including enzalutamide, estradiol and genistein. However, there are issues and challenges before using these drugs clinically that need to be considered carefully such as safety and bioavailability of the drugs, as well as using of proper delivery methods to deliver the drugs successfully to specific target regions.

Acknowledgements This work was supported by The Hashemite University, Jordan.

Author contributions Dr. Ismail Mahmoud: Conception, designing and writing of the manuscript; Dr. Yazun Jarrar: Writing and revising of the manuscript.

Data availability All data generated or analyzed during this study are included in this published article [and its supplementary information files].

\section{Declarations}

Conflict of interest The authors declare no conflict of interest.

\section{References}

1. Soleimani M (2020) Acute kidney injury in SARS-CoV-2 infection: direct effect of virus on kidney proximal tubule cells. Int J Mol Sci 21(9):3275. https://doi.org/10.3390/ijms21093275

2. Xiao F, Tang M, Zheng X, Liu Y, Li X, Shan H (2020) Evidence for gastrointestinal infection of SARS-CoV-2. Gastroenterology 158(6):1831-1833.e3. https://doi.org/10.1053/j.gastro.2020.02. 055

3. Wang Y, Liu S, Liu H, Li W, Lin F, Jiang L, Li X, Xu P, Zhang L, Zhao L, Cao Y, Kang J, Yang J, Li L, Liu X, Li Y, Nie R, Mu J, Lu F, Zhao S, Lu J, Zhao J (2020) SARS-CoV-2 infection of the liver directly contributes to hepatic impairment in patients with COVID-19. J Hepatol 73(4):807-816. https://doi.org/10.1016/j. jhep.2020.05.002

4. Mahmoud IS, Jarrar YB, Alshaer W, Ismail S (2020) SARSCoV-2 entry in host cells-multiple targets for treatment and prevention. Biochimie 175:93-98. https://doi.org/10.1016/j.biochi. 2020.05.012

5. Lamers MM, Beumer J, van der Vaart J, Knoops K, Puschhof J, Breugem TI, Ravelli RBG, van Schayck JP, Mykytyn AZ, Duimel HQ, van Donselaar E, Riesebosch S, Kuijpers HJH, Schipper D, van de Wetering WJ, de Graaf M, Koopmans M, Cuppen E, Peters PJ, Haagmans BL, Clevers H (2020) SARS-CoV-2 productively infects human gut enterocytes. Science 369(6499):50-54. https:// doi.org/10.1126/science.abc1669

6. Cheung KS, Hung IFN, Chan PPY, Lung KC, Tso E, Liu R, Ng YY, Chu MY, Chung TWH, Tam AR, Yip CCY, Leung KH, Fung AY, Zhang RR, Lin Y, Cheng HM, Zhang AJX, To KKW, Chan KH, Yuen KY, Leung WK (2020) Gastrointestinal manifestations of SARS-CoV-2 infection and virus load in fecal samples from a Hong Kong cohort: systematic review and meta-analysis. Gastroenterology 159(1):81-95. https://doi.org/10.1053/j.gastro.2020. 03.065

7. Mao R, Qiu Y, He JS, Tan JY, Li XH, Liang J, Shen J, Zhu LR, Chen Y, Iacucci M, Ng SC, Ghosh S, Chen MH (2020) Manifestations and prognosis of gastrointestinal and liver involvement 
in patients with COVID-19: a systematic review and metaanalysis. Lancet Gastroenterol Hepatol 5(7):667-678. https:// doi.org/10.1016/S2468-1253(20)30126-6 (Erratum In: Lancet Gastroenterol Hepatol 2020;5(7):e6)

8. Pan L, Mu M, Yang P, Sun Y, Wang R, Yan J, Li P, Hu B, Wang J, Hu C, Jin Y, Niu X, Ping R, Du Y, Li T, Xu G, Hu Q, Tu L (2020) Clinical characteristics of COVID-19 patients with digestive symptoms in Hubei, China: a descriptive, cross-sectional, multicenter study. Am J Gastroenterol 115(5):766-773. https://doi.org/10.14309/ajg.0000000000000620

9. Bugge TH, Antalis TM, Wu Q (2009) Type II transmembrane serine proteases. J Biol Chem 284(35):23177-23181. https:// doi.org/10.1074/jbc.R109.021006

10. Lin B, Ferguson C, White JT, Wang S, Vessella R, True LD, Hood L, Nelson PS (1999) Prostate-localized and androgenregulated expression of the membrane-bound serine protease TMPRSS2. Cancer Res 59(17):4180-4184

11. Thunders M, Delahunt B (2020) Gene of the month: TMPRSS2 (transmembrane serine protease 2). J Clin Pathol 73(12):773776. https://doi.org/10.1136/jclinpath-2020-206987

12. Clinckemalie L, Spans L, Dubois V, Laurent M, Helsen C, Joniau S, Claessens F (2013) Androgen regulation of the TMPRSS2 gene and the effect of a SNP in an androgen response element. Mol Endocrinol 27(12):2028-2040. https://doi.org/10. 1210/me.2013-1098

13. David A, Khanna T, Beykou M, Hanna G, Sternberg M (2020) Structure, function and variants analysis of the androgen-regulated TMPRSS2, a drug target candidate for COVID-19 infection. BioRxiv. https://doi.org/10.1101/2020.05.26.116608

14. Afar DE, Vivanco I, Hubert RS, Kuo J, Chen E, Saffran DC, Raitano AB, Jakobovits A (2001) Catalytic cleavage of the androgen-regulated TMPRSS2 protease results in its secretion by prostate and prostate cancer epithelia. Cancer Res 61(4):1686-1692

15. Hooper JD, Clements JA, Quigley JP, Antalis TM (2001) Type II transmembrane serine proteases. Insights into an emerging class of cell surface proteolytic enzymes. J Biol Chem 276(2):857-60. https://doi.org/10.1074/jbc.R000020200

16. Glowacka I, Bertram S, Müller MA, Allen P, Soilleux E, Pfefferle S, Steffen I, Tsegaye TS, He Y, Gnirss K, Niemeyer D, Schneider H, Drosten C, Pöhlmann S (2011) Evidence that TMPRSS2 activates the severe acute respiratory syndrome coronavirus spike protein for membrane fusion and reduces viral control by the humoral immune response. J Virol 85(9):4122-4134. https://doi.org/10. 1128/JVI.02232-10

17. Hoffmann M, Kleine-Weber H, Schroeder S, Krüger N, Herrler T, Erichsen S, Schiergens TS, Herrler G, Wu NH, Nitsche A, Müller MA, Drosten C, Pöhlmann S (2020) SARS-CoV-2 cell entry depends on ACE2 and TMPRSS2 and is blocked by a clinically proven protease inhibitor. Cell 181(2):271-280.e8. https://doi.org/ 10.1016/j.cell.2020.02.052

18. Heurich A, Hofmann-Winkler H, Gierer S, Liepold T, Jahn O, Pöhlmann S (2014) TMPRSS2 and ADAM17 cleave ACE2 differentially and only proteolysis by TMPRSS2 augments entry driven by the severe acute respiratory syndrome coronavirus spike protein. J Virol 88(2):1293-1307. https://doi.org/10.1128/ JVI.02202-13

19. Iwata-Yoshikawa N, Okamura T, Shimizu Y, Hasegawa H, Takeda M, Nagata N (2019) TMPRSS2 contributes to virus spread and immunopathology in the airways of murine models after coronavirus infection. J Virol 93(6):e01815-e1818. https://doi.org/10. 1128/JVI.01815-18

20. Matsuyama S, Nao N, Shirato K, Kawase M, Saito S, Takayama I, Nagata N, Sekizuka T, Katoh H, Kato F, Sakata M, Tahara M, Kutsuna S, Ohmagari N, Kuroda M, Suzuki T, Kageyama T, Takeda M (2020) Enhanced isolation of SARS-CoV-2 by TMPRSS2-expressing cells. Proc Natl Acad Sci U S A 117(13):7001-7003. https://doi.org/10.1073/pnas.2002589117

21. Ni W, Yang X, Yang D, Bao J, Li R, Xiao Y, Hou C, Wang H, Liu J, Yang D, Xu Y, Cao Z, Gao Z (2020) Role of angiotensinconverting enzyme 2 (ACE2) in COVID-19. Crit Care 24(1):422. https://doi.org/10.1186/s13054-020-03120-0

22. Li F, Li W, Farzan M, Harrison SC (2005) Structure of SARS coronavirus spike receptor-binding domain complexed with receptor. Science 309(5742):1864-1868. https://doi.org/10.1126/scien ce. 1116480

23. Zipeto D, Palmeira JDF, Argañaraz GA, Argañaraz ER (2020) ACE2/ADAM17/TMPRSS2 interplay may be the main risk factor for COVID-19. Front Immunol 11:576745. https://doi.org/10. 3389/fimmu.2020.576745

24. Lin L, Jiang X, Zhang Z, Huang S, Zhang Z, Fang Z, Gu Z, Gao L, Shi H, Mai L, Liu Y, Lin X, Lai R, Yan Z, Li X, Shan H (2020) Gastrointestinal symptoms of 95 cases with SARSCoV-2 infection. Gut 69(6):997-1001. https://doi.org/10.1136/ gutjnl-2020-321013

25. Holshue ML, DeBolt C, Lindquist S, Lofy KH, Wiesman J, Bruce H, Spitters C, Ericson K, Wilkerson S, Tural A, Diaz G, Cohn A, Fox L, Patel A, Gerber SI, Kim L, Tong S, Lu X, Lindstrom S, Pallansch MA, Weldon WC, Biggs HM, Uyeki TM, Pillai SK, Washington State 2019-nCoV Case Investigation Team (2020) First case of 2019 novel coronavirus in the United States. N Engl J Med 382(10):929-936. https://doi.org/10.1056/NEJMoa2001191

26. Lee S, Yoon GY, Myoung J, Kim SJ, Ahn DG (2020) Robust and persistent SARS-CoV-2 infection in the human intestinal brush border expressing cells. Emerg Microbes Infect 9(1):2169-2179. https://doi.org/10.1080/22221751.2020.1827985

27. Zang R, Gomez Castro MF, McCune BT, Zeng Q, Rothlauf PW, Sonnek NM, Liu Z, Brulois KF, Wang X, Greenberg HB et al (2020) TMPRSS2 and TMPRSS4 promote SARS-CoV-2 infection of human small intestinal enterocytes. Sci Immunol. https://doi. org/10.1126/sciimmunol.abc3582

28. Gkogkou E, Barnasas G, Vougas K, Trougakos IP (2020) Expression profiling meta-analysis of ACE2 and TMPRSS2, the putative anti-inflammatory receptor and priming protease of SARS-CoV-2 in human cells, and identification of putative modulators. Redox Biol 36:101615. https://doi.org/10.1016/j.redox.2020.101615

29. Piva F, Sabanovic B, Cecati M, Giulietti M (2021) Expression and co-expression analyses of TMPRSS2, a key element in COVID19. Eur J Clin Microbiol Infect Dis 40(2):451-455. https://doi.org/ 10.1007/s10096-020-04089-y

30. Kumar A, Faiq MA, Pareek V, Raza K, Narayan RK, Prasoon P, Kumar P, Kulandhasamy M, Kumari C, Kant K, Singh HN, Qadri R, Pandey SN, Kumar S (2020) Relevance of SARS-CoV-2 related factors ACE2 and TMPRSS2 expressions in gastrointestinal tissue with pathogenesis of digestive symptoms, diabetes-associated mortality, and disease recurrence in COVID-19 patients. Med Hypotheses 144:110271. https://doi.org/10.1016/j.mehy.2020. 110271

31. Das S, Jayaratne R, Barrett KE (2018) The role of ion transporters in the pathophysiology of infectious diarrhea. Cell Mol Gastroenterol Hepatol 6(1):33-45. https://doi.org/10.1016/j.jcmgh.2018. 02.009

32. Hoffmann M, Mosbauer K, Hofmann-Winkler H, Kaul A, KleineWeber H, Kruger N, Gassen NC, Muller MA, Drosten C, Pohlmann S (2020) Chloroquine does not inhibit infection of human lung cells with SARS-CoV-2. Nature 585:588-590. https://doi. org/10.1038/s41586-020-2575-3

33. Bestle D, Heindl MR, Limburg H, Van Lam van T, Pilgram O, Moulton H, Stein DA, Hardes K, Eickmann M, Dolnik O et al (2020) TMPRSS2 and furin are both essential for proteolytic activation of SARS-CoV-2 in human airway cells. Life Sci Alliance. https://doi.org/10.26508/1sa.202000786 
34. Ko CJ, Hsu TW, Wu SR, Lan SW, Hsiao TF, Lin HY, Lin HH, Tu HF, Lee CF, Huang CC et al (2020) Inhibition of TMPRSS2 by $\mathrm{HAI}-2$ reduces prostate cancer cell invasion and metastasis. Oncogene 39:5950-5963. https://doi.org/10.1038/s41388-020-01413-w

35. Chu M, Chang Y, Wang N, Li W, Li P, Gao WQ (2014) Hypermethylation-mediated transcriptional repression of TMPRSS2 in androgen receptor-negative prostate cancer cells. Exp Biol Med (Maywood) 239:823-828. https://doi.org/10.1177/1535370214 531880

36. Scaglione F, Petrini O (2019) Mucoactive agents in the therapy of upper respiratory airways infections: fair to describe them just as mucoactive? Clin Med Insights Ear Nose Throat 12:1179550618821930. https://doi.org/10.1177/1179550618 821930

37. Beeh KM, Beier J, Esperester A, Paul LD (2008) Antiinflammatory properties of ambroxol. Eur J Med Res 13:557-562

38. Yang B, Yao DF, Ohuchi M, Ide M, Yano M, Okumura Y, Kido H (2002) Ambroxol suppresses influenza-virus proliferation in the mouse airway by increasing antiviral factor levels. Eur Respir J 19:952-958. https://doi.org/10.1183/09031936.02.00253302

39. Lucas JM, Heinlein C, Kim T, Hernandez SA, Malik MS, True LD, Morrissey C, Corey E, Montgomery B, Mostaghel E, Clegg N, Coleman I, Brown CM, Schneider EL, Craik C, Simon JA, Bedalov A, Nelson PS (2014) The androgen-regulated protease TMPRSS2 activates a proteolytic cascade involving components of the tumor microenvironment and promotes prostate cancer metastasis. Cancer Discov 4(11):1310-1325. https://doi.org/10. 1158/2159-8290.CD-13-1010

40. Ansarin K, Tolouian R, Ardalan M, Taghizadieh A, Varshochi M, Teimouri S, Vaezi T, Valizadeh H, Saleh P, Safiri S, Chapman KR (2020) Effect of bromhexine on clinical outcomes and mortality in COVID-19 patients: a randomized clinical trial. Bioimpacts 10(4):209-215. https://doi.org/10.34172/bi.2020.27

41. Kantar A, Klimek L, Cazan D, Sperl A, Sent U, Mesquita M (2020) An overview of efficacy and safety of ambroxol for the treatment of acute and chronic respiratory diseases with a special regard to children. Multidiscip Respir Med 15:511. https://doi.org/ $10.4081 / \mathrm{mrm} .2020 .511$

42. Luo X, Zhou GZ, Zhang Y, Peng LH, Zou LP, Yang YS (2020) Coronaviruses and gastrointestinal diseases. Mil Med Res 7:49. https://doi.org/10.1186/s40779-020-00279-z

43. Han SJ, Kim HS, Kim KI, Whang SM, Hong KS, Lee WK, Lee SH (2011) Use of nafamostat mesilate as an anticoagulant during extracorporeal membrane oxygenation. J Korean Med Sci 26:945-950. https://doi.org/10.3346/jkms.2011.26.7.945

44. Warnaar N, Mallett SV, Klinck JR, de Boer MT, Rolando N, Burroughs AK, Jamieson NV, Rolles K, Porte RJ (2009) Aprotinin and the risk of thrombotic complications after liver transplantation: a retrospective analysis of 1492 patients. Liver Transpl 15:747-753. https://doi.org/10.1002/lt.21768

45. Motoo Y (2007) Antiproteases in the treatment of chronic pancreatitis. JOP 8:533-537

46. Levy JH, Sypniewski E (2004) Aprotinin: a pharmacologic overview. Orthopedics 27:s653658

47. Fuwa M, Kageyama M, Ohashi K, Sasaoka M, Sato R, Tanaka M, Tashiro K (2019) Nafamostat and sepimostat identified as novel neuroprotective agents via NR2B N-methyl-D-aspartate receptor antagonism using a rat retinal excitotoxicity model. Sci Rep 9:20409. https://doi.org/10.1038/s41598-019-56905-x

48. Roomi M, Khan Y (2020) Potential compounds for the inhibition of TMPRSS2. ChemRxiv. https://doi.org/10.26434/chemrxiv. 12727787.v1

49. Bojkova D, Bechtel M, McLaughlin KM, McGreig JE, Klann K, Bellinghausen C, Rohde G, Jonigk D, Braubach P, Ciesek S et al (2020) Aprotinin inhibits SARS-CoV-2 replication. Cells. https:// doi.org/10.3390/cells9112377
50. Ovcharenko AV, Zhirnov OP (1994) Aprotinin aerosol treatment of influenza and paramyxovirus bronchopneumonia of mice. Antiviral Res 23:107-118. https://doi.org/10.1016/0166-3542(94) 90038-8

51. Rensi S, Altman RB, Liu T, Lo YC, McInnes G, Derry A, Keys A (2020) Homology modeling of TMPRSS2 yields candidate drugs that may inhibit entry of SARS-CoV-2 into human cells. ChemRxiv. https://doi.org/10.26434/chemrxiv.12009582.v1

52. Yamamoto M, Matsuyama S, Li X, Takeda M, Kawaguchi Y, Inoue JI, Matsuda Z (2016) Identification of nafamostat as a potent inhibitor of middle east respiratory syndrome coronavirus $\mathrm{S}$ protein-mediated membrane fusion using the split-protein-based cell-cell fusion assay. Antimicrob Agents Chemother 60:65326539. https://doi.org/10.1128/AAC.01043-16

53. Zhou Y, Vedantham P, Lu K, Agudelo J, Carrion R Jr, Nunneley JW, Barnard D, Pohlmann S, McKerrow JH, Renslo AR et al (2015) Protease inhibitors targeting coronavirus and filovirus entry. Antiviral Res 116:76-84. https://doi.org/10.1016/j.antiv iral.2015.01.011

54. Muto S, Imai M, Asano Y (1994) Mechanisms of the hyperkalaemia caused by nafamostat mesilate: effects of its two metabolites on $\mathrm{Na}+$ and $\mathrm{K}+$ transport properties in the rabbit cortical collecting duct. Br J Pharmacol 111:173-178. https://doi.org/10.1111/j. 1476-5381.1994.tb14040.x

55. Kim HS, Lee KE, Oh JH, Jung CS, Choi D, Kim Y, Jeon JS, Han DC, Noh H (2016) Cardiac arrest caused by nafamostat mesilate. Kidney Res Clin Pract 35:187-189. https://doi.org/10.1016/j.krcp. 2015.10.003

56. Strope JD, Chau CH, Figg WD (2020) Are sex discordant outcomes in COVID-19 related to sex hormones? Semin Oncol 47:335-340. https://doi.org/10.1053/j.seminoncol.2020.06.002

57. AlAwlaqi A, Amor H, Hammadeh ME (2017) Role of hormones in hypoactive sexual desire disorder and current treatment. J Turk Ger Gynecol Assoc 18:210-218. https://doi.org/10.4274/jtgga. 2017.0071

58. La Vignera S, Condorelli RA, Cannarella R, Duca Y, Calogero AE (2018) Sport, doping and female fertility. Reprod Biol Endocrinol 16(1):108. https://doi.org/10.1186/s12958-018-0437-8

59. Wang X, Dhindsa R, Povysil G, Zoghbi A, Motelow J, Hostyk J, Nickols N, Rettig M, Goldstein D (2020) TMPRSS2 transcriptional inhibition as a therapeutic strategy for COVID-19. Preprints Org. https://doi.org/10.20944/preprints202003.0360.v2

60. Bwire GM (2020) Coronavirus: why men are more vulnerable to covid-19 than women? SN Compr Clin Med. https://doi.org/10. 1007/s42399-020-00341-w

61. Borges do Nascimento IJ, Cacic N, Abdulazeem HM, von Groote TC, Jayarajah U, Weerasekara I, Esfahani MA, Civile VT, Marusic A, Jeroncic A, Carvas Junior N, Pericic TP, Zakarija-Grkovic I, Meirelles Guimarães SM, Luigi Bragazzi N, Bjorklund M, SofiMahmudi A, Altujjar M, Tian M, Arcani DMC, O’Mathúna DP, Marcolino MS (2020) Novel coronavirus infection (COVID-19) in humans: a scoping review and meta-analysis. J Clin Med 9(4):941. https://doi.org/10.3390/jcm9040941

62. Zanasi A, Mazzolini M, Kantar A (2017) A reappraisal of the mucoactive activity and clinical efficacy of bromhexine. Multidiscip Respir Med 12:7. https://doi.org/10.1186/s40248-017-0088-1

63. Brown JR, Toler AW, Kramer RS, Landis RC (2009) Anti-inflammatory effect of aprotinin: a meta-analysis. J Extra Corpor Technol 41(2):79-86

64. Talukdar R, Tandon RK (2008) Pancreatic stellate cells: new target in the treatment of chronic pancreatitis. J Gastroenterol Hepatol 23(1):34-41. https://doi.org/10.1111/j.1440-1746.2007. 05206.x

65. Iwaki M, Ino Y, Motoyoshi A, Ozeki M, Sato T, Kurumi M, Aoyama T (1986) Pharmacological studies of FUT-175, Nafamostat mesilate V. Effects on the pancreatic enzymes and experimental 
acute pancreatitis in rats. Jpn J Pharmacol 41(2):155-62. https:// doi.org/10.1254/jjp.41.155

66. Mitchell MJ, Smith SL, Johnson S, Morgan ED (1997) Effects of the neem tree compounds azadirachtin, salannin, nimbin, and 6-desacetylnimbin on ecdysone 20-monooxygenase activity. Arch Insect Biochem Physiol 35(1-2):199-209. https://doi.org/10.1002/ (SICI)1520-6327(1997)35:1/2\%3c199::AID-ARCH18\%3e3.0. $\mathrm{CO} ; 2-6$

67. Stompor M (2020) A review on sources and pharmacological aspects of sakuranetin. Nutrients 12(2):513. https://doi.org/10. 3390/nu12020513

68. Dhakad AK, Pandey VV, Beg S, Rawat JM, Singh A (2018) Biological, medicinal and toxicological significance of eucalyptus leaf essential oil: a review. J Sci Food Agric 98(3):833-848. https://doi.org/10.1002/jsfa.8600

69. Rwangabo PC, Claeys M, Pieters L, Corthout J, Vanden Berghe DA, Vlietinck AJ (1988) Umuhengerin, a new antimicrobially active flavonoid from Lantana trifolia. J Nat Prod 51(5):966-968. https://doi.org/10.1021/np50059a026
70. Deroo BJ, Korach KS (2006) Estrogen receptors and human disease. J Clin Invest 116(3):561-570. https://doi.org/10.1172/JCI27 987

71. Lecomte S, Demay F, Ferrière F, Pakdel F (2017) Phytochemicals targeting estrogen receptors: beneficial rather than adverse effects? Int J Mol Sci 18(7):1381. https://doi.org/10.3390/ijms18071381

72. Menon MP, Higano CS (2013) Enzalutamide, a second generation androgen receptor antagonist: development and clinical applications in prostate cancer. Curr Oncol Rep 15(2):69-75. https://doi. org/10.1007/s11912-013-0293-9

Publisher's Note Springer Nature remains neutral with regard to jurisdictional claims in published maps and institutional affiliations. 